\title{
Measuring hydrodynamics and sediment transport processes in the Dee Estuary
}

\author{
R. Bolaños and A. Souza \\ National Oceanography Centre, Joseph Proudman Building, 6 Brownlow Street, Liverpool, L3 5DA, UK \\ Received: 15 February 2010 - Published in Earth Syst. Sci. Data Discuss.: 3 March 2010 \\ Revised: 13 May 2010 - Accepted: 20 May 2010 - Published: 14 June 2010
}

\begin{abstract}
The capability of monitoring and prediction in the marine environment provides information that may allow sustainable development of coastal and offshore regions. Therefore, the continuous measurement of environmental processes becomes an important source of information. The present paper shows data collected during 6 years, and in particular during 2008, in the Dee Estuary. The aim of the data collection is to improve the observations of the mobile sediments in coastal areas and its forcing hydrodynamics and turbulence. Data includes information from the deployment of instrumented rigs measuring sediment in suspension, currents, waves, sea level, sediment size and bedforms as well as cruise work including grab sampling, CTD profiles and side-scan sonar. The data cover flood and ebb tides during spring and neap periods with moderate and mild wave events, thus, having a good coverage of the processes needed to improve knowledge of sediment transport and the parameterizations used in numerical modelling. The data, in raw and treated, are being banked at BODC (British Oceanographic Data Centre, http://www.bodc.ac.uk/) which is the formal British organization for looking after and distributing data concerning the marine environment.
\end{abstract}

\section{Introduction}

Coastal areas support many human activities of economic, industrial and leisure importance. Moreover, they represent a very important habitat for many marine and bird species. In order to manage properly such areas, knowledge of the physical, biological and chemical processes is necessary and therefore the observation, quantification and simulation of such processes are very important. Coastal ecosystems are experiencing changes affecting the dynamic boundary between the land and the sea. Coastal waves and currents are highly variable and can have a significant impact on human activities and structures. Therefore, the continuous research and improvement of environmental monitoring has become a vital issue for the safety and well-being of coastal society. The capability of monitoring and prediction in the marine environment provides information that may allow sustainable development of coastal and offshore regions (Pinardi and Woods, 2002; GOOS, 2003).

Correspondence to: R. Bolaños (rbol@pol.ac.uk)
In recent years, the scientific community has been paying more attention to several aspects of wave-current-bedsediment interaction. Mastenbroek et al. (1993) showed how a wave-dependent bottom drag coefficient improved the results of a 2-D storm surge model in the North Sea. Baumert et al. (2000), Souza et al. (2001) and Bolaños et al. (2005), using a coupled wave-tidal-circulation model, showed the relevance of wave action over the stress at the sea bed and thereby the erosion and suspension of particulate matter. Brown and Wolf (2009) improved storm surge modelling by considering a wave dependent surface stress. Thus, simultaneous measurements of such processes are necessary, though not common, to understand and improve its modelling. There is a pressing need for improved observations of the mobile sediments in coastal areas in order to upgrade modelling systems, ultimately allowing the appropriate management of nearshore and estuarine areas that are under increasing pressure.

The data collection presented in this paper aims to improve the observations of the mobile sediments in coastal areas, to advance research on observational techniques, especially using acoustic methods for measuring sediment concentrations, bed forms and transport. To advance understanding of critical aspects of the key processes, for example bedform evolution, modes of sediment entrainment and the impact of mixed 


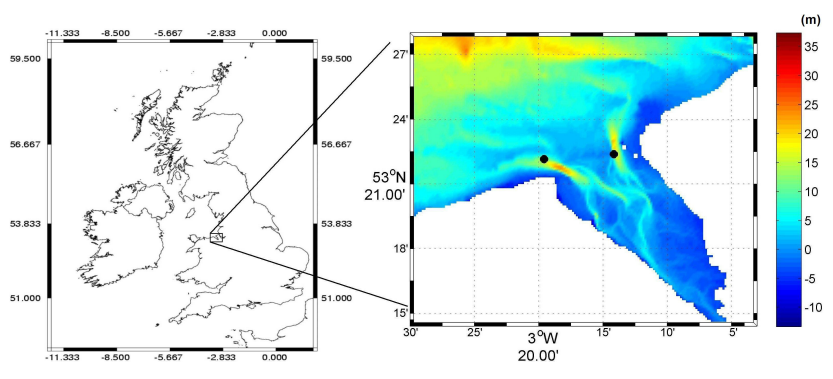

Figure 1. Location of the Dee Estuary in the Irish Sea. Right figure shows the Dee bathymetry and location of rigs at the Welsh (West) and Hilbre (East) channels. Colour scale shows water depth in meters, negative values represent height above mean sea level.

sediments, in combined waves and currents; and to make a critical assessment of the extent to which the predictive capabilities related to sand transport remain valid in a mixed sediment environment. The data set represent a unique source of information due to the simultaneous measurements of the processes involved in sediment transport.

The Dee (Moore et al., 2009; Simpson et al., 2004) is a macrotidal estuary characterized by the presence of waves at its outer margins, strong tidal flows in its channels, and a mixed seabed usually muddy sands or sandy muds. The overall transport direction, in or out of the main outer channels of the estuary, is probably grain-size dependent. The Dee is, thus, a conveniently located "natural laboratory".

The present paper shows data collected during 6 years, and in particular during 2008. First a detailed description of the Dee Estuary is given. Then details of rigs and instrumentations deployed are discussed together with an overview of the data and the environmental conditions during the recording period. Comprehensive data of the Dee Experiment are also summarized in Sect. 6. Finally the conclusions are presented outlining the key aspects that can be addressed with this data set.

\section{The Dee Estuary}

The Dee is a macrotidal, funnel-shaped estuary situated in the eastern Irish Sea (Fig. 1). It has a length of about $30 \mathrm{~km}$, with a maximum width of $8.5 \mathrm{~km}$ at the mouth of the estuary. The average tidal prism in the Dee is $4 \times 10^{8} \mathrm{~m}^{3}$, annual mean river discharge is only of $31 \mathrm{~m}^{3} / \mathrm{s}$ (with peak flows of the order of $300 \mathrm{~m}^{3} / \mathrm{s}$ ) making the Dee a tidal dominated estuary. Tidal range during mean spring at Hilbre Island is in the order of $10 \mathrm{~m}$. A tidal bore has been reported to occur in the canalised upper part of the estuary (Simpson et al., 2004). Moore et al. (2009) report a sediment import into the estuary, but it is suggested that the Dee could be reaching a morphological equilibrium and that the rate of accretion may decrease in the future. The main channel bifurcates $12 \mathrm{~km}$ seaward from the canalised river at the head of the estuary, resulting in two deep channels extending into Liverpool Bay. The Dee Estuary presents a mixture of sediments containing a range of non-cohesive and cohesive sediments (Baas, J. H.: Bottom sediment characteristics at (mini)STABLE sites, personal communication, 4th FORMOST Meeting, 2009) and, therefore, the threshold of motion of the bed might be a complex process dependent on several conditions. The estuary is a major wildlife area and is one of the most important estuaries in Britain and amongst the most important in Europe for its populations of waders and wildfowl. The two shorelines of the estuary show a marked contrast between the industrialised usage of the coastal belt in Wales and residential and recreational usage in England. The estuary has been subject of several man made modifications such as canalisations and training wall causing siltation and accretion on the eastern shore and colonisation of some areas by saltmarsh.

The estuary contains extensive areas of intertidal sand and mudflats (Hutchinson, 1994; Hutchinson and Prandle, 1994) which support a variable but characteristic benthic fauna depending on the nature of the substrate. Large areas of saltmarsh also occur at its head and along part of its northeastern shore. The three sandstone islands which comprise the Hilbre Island complex represent the only natural hard rock coast within the estuary.

\section{Instrumentation and deployments}

The Dee Estuary has been subject of study and measurements by the Proudman Oceanographic Laboratory (POL, renamed the National Oceanography Centre from 1 April 2010) since 2004 when deployment of rigs and cruises in the area started to take place. Recently, within the NERC funded FORMOST (Field observation and modelling of the sediment triad) project (http://www.pol.ac.uk/home/research/ formost/), measurements were carried out during 2008 and 2009.

The measurement program in the Dee during 2008 consisted of the deployment of 2 recent versions of STABLE (Sediment Transport and Boundary Layer Equipment) rigs. STABLE is a platform to study near-bed turbulent currents and associated sediment-dynamics. The biggest and most complex structure designed and built by the Mechanical Engineering group at POL is the STABLE-III equipment (Fig. 2). STABLE-III is the third generation of this apparatus which was conceived originally in 1981. It measures the interactions between turbulent currents and sediments at the sea-bed. It is a tripod standing about $2.5 \mathrm{~m}$ high and the feet occupy a circle about $3.5 \mathrm{~m}$ in diameter: it weighs about $2500 \mathrm{~kg}$ (Williams et al., 2003). Mini-STABLE (Fig. 2) is a smaller version of STABLE-III. STABLE-III and miniSTABLE were deployed in the Hilbre Channel and Welsh Channel respectively (Fig. 1).

The period of deployments was from mid February to mid March, the first one to be deployed was mini-STABLE 

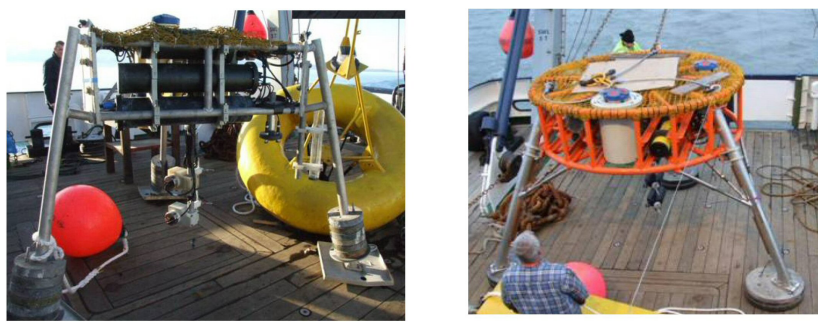

Figure 2. Mini-STABLE (left) and STABLE-III (right) during the deployment manoeuvres on the Prince Madog.

(12 February 2008) in the Welsh channel, and STABLEIII two days later in Hilbre channel. Rigs were equipped with different instruments to measure currents, waves, concentration of sediment in suspension, sediment size, salinity and temperature. Instruments used were ADVs (Acoustic Doppler Velocimeter, Sontek ADVocean $5 \mathrm{MHz}$ ) able to rapidly and accurately sample 3 -D current component in a small sampling volume by using the pulse-coherent technique.

ABS (Acoustic Backscatter System, built at POL) measures the strength of backscatter signal that can be inverted to obtain concentration and size of particles in suspension in the water column. The use of acoustic backscatter (ABS) techniques to measure suspended sediment dates back to the 1980s (Crawford and Hay, 1993; Young et al., 1982; Thorne and Campbell, 1992).

LISST (Laser In Situ Scattering and Transmissometry, from Sequoia) designed to measure particle size based on the principle of laser diffraction. The standard processing software supplied with the LISST computes the volume concentration in units of microlitres per litre (ul/l). The LISST laser optics must be checked on a regular basis to ensure that they remain properly aligned (Styles, 2006) and background scatter calibration must be also performed.

ADCP (Acoustic Doppler Current Profiler, from Teledyne RD Instruments), which measures the velocity of water using a physical principle similar to the ADVs. Traditionaly ADCP have been used to study current profiles with resolution of the order of $0.5 \mathrm{~m}$ but nowadays ADCP instruments can be used for resolution of up to $1 \mathrm{~cm}$ allowing the study of turbulence and sediments transport.

The rigs also contained ripple profilers, mini-STABLE had a line scan ripple profiler and STABLE-III a 3-D scanner which is a line scan ripple profiler that rotates to provide an area coverage. The transducer allows to find the bed position within a spatial resolution of about $5 \mathrm{~mm}$ and with an error of $0.01 \mathrm{~m}$ (Williams et al., 2004, 2005).

In order to measure turbidity (suspended particulate matter) a series of optical backscatter sensors (OBS, from Campbell Scientific, Inc.) were installed to the ADVs. OBS measure turbidity on NTU units, the instruments were set to a low turbidity range. Serial numbers of the OBS are T8193,
T8194 and T8195 with the calibration formula as

$2.5 \times 10^{-6} X^{2}+0.0946201 X+0.061581$,

$2.4 \times 10^{-6} X^{2}+0.094505 X-0.0493607$ and

$2.4 \times 10^{-6} X^{2}+0.0916872 X+0.0881808$ respectively.

Pre-deployment instrument operations consisted of typical servicing, calibration and testing of instruments. Synchronization of clocks were performed and instruments were set to start the recording at 06:00 GMT on 12 February 2008 for mini-STABLE and 06:00 GMT on 14 February 2008 for STABLE-III.

In order to deploy and recover the rigs, an oceanographic research vessel (Prince Madog) was used. The deployment and recovery periods were used also to perform CTD profile and LISST station, grab sampling and side-scan sonar transects.

\subsection{Welsh channel deployment}

All parts for mini-STABLE were transported to Menai Bridge, UK, and loaded onto the Prince Madog and then deployed in the Welsh channel. Instruments on the rig were 2 ADVs, 1 ABS, a line scan ripple profiler, a sediment trap, a LISST and ADCP. Unfortunately the ADCP and ABS were damaged and data were lost. Figure 2 shows the rig before the deployment manoeuvres. Table 1 shows the summary of the instruments, their position on the frame and some sampling information. High frequency sampling was used in order to have turbulence and small/fast processes information.

\subsection{Hilbre channel deployment}

STABLE-III was constructed at POL's Vittoria Dock site (Birkenhead, UK) in the weeks prior to its deployment in the Hilbre Channel. The frame had 3 ADVs in horizontal position, 2 ADCPs, 3 OBS sensors linked to ADVs, an ABS, a LISST, a sensor for temperature and salinity and a Settlingtube sediment trap. However, two of the OBS did not record properly. Figure 2 shows the rig at the Prince Madog just before deployment. Table 2 shows a summary of the rig instrumentation with the sampling strategy used.

\section{Data treatment and access}

ADVs data have been cleaned and flagged for possible spikes that can appear in this kind of instruments. The approach taken was following Goring and Nikora (2002) and modified by Wahl (2003). The method is based in 3-D Poincare map in which each component of velocity and its first and second derivative are plotted against each other. The points located outside of the ellipsoid in the Poincare map are excluded or replaced by a polynomial interpolation. This method has been used by Mori et al. (2007) to clean ADV data in bubbly 
Table 1. Instrumentation in mini-STABLE rig deployed in the Welsh Channel.

\begin{tabular}{lll}
\hline \multicolumn{3}{l}{ Mini-STABLE: Welsh Channel, $53^{\circ} 22.156^{\prime} \mathrm{N} 3^{\circ} 19.577^{\prime} \mathrm{W}, 12 \mathrm{Feb} 2008-13 \mathrm{Mar} 2008$} \\
\hline Instrument & High above the bed $(\mathrm{m})$ & Sampling \\
\hline ADV G412+B331 & 0.63 & $16 \mathrm{~Hz}, 20$ min burst every $1 \mathrm{~h}$ \\
ADV G250+B233 & 0.35 & $16 \mathrm{~Hz}, 20$ min burst every $1 \mathrm{~h}$ \\
Line-scan Ripple profiler & 1.04 & $1 \mathrm{scan}$ every 5 min \\
Sediments trap & 1.18 & \\
LISST-100 & 1.56 & $0.025 \mathrm{~Hz}, 20$ min every hour \\
\hline
\end{tabular}

Table 2. Instrumentation in STABLE-III rig deployed in Hilbre Channel.

\begin{tabular}{|c|c|c|}
\hline \multicolumn{3}{|c|}{ STABLE-III: Hilbre Channel, 53²2.382’ N 3¹4.147’ W, 14 Feb 2008-11 Mar 2008} \\
\hline Instrument & High above the bed (m) & Sampling \\
\hline ADV G496+B281 & 1 & $8 \mathrm{~Hz}, 20 \mathrm{~min}$ burst every $1 \mathrm{~h}$ \\
\hline ADV G355+B285 & 0.7 & $8 \mathrm{~Hz}, 20 \mathrm{~min}$ burst every $1 \mathrm{~h}$ \\
\hline ADV G358+B292 & 0.4 & $8 \mathrm{~Hz}, 20 \mathrm{~min}$ burst every $1 \mathrm{~h}$ \\
\hline OBS T8193 & 1 & $8 \mathrm{~Hz}, 20 \mathrm{~min}$ burst every $1 \mathrm{~h}$ \\
\hline ABS & 1.2 & 128 vertical bins $(\mathrm{cm}), 20 \mathrm{~min}$ burst every hour \\
\hline LISST100X & 1.82 & $0.025 \mathrm{~Hz}, 20 \mathrm{~min}$ every hour \\
\hline CT probe 7216 & 1 & $8 \mathrm{~Hz}, 20 \mathrm{~min}$ burst every hour \\
\hline CT probe 7217 & 0.7 & $8 \mathrm{~Hz}, 20 \mathrm{~min}$ burst every hour \\
\hline CT probe 7218 & 0.4 & $8 \mathrm{~Hz}, 20 \mathrm{~min}$ burst every hour \\
\hline 3-D ripple profiler & 1.34 & 1 3-D image every hour \\
\hline Settling tube sediment trap. & 1.05 & \\
\hline ADCP $600 \mathrm{~Hz}$ & 2.3 & Bin size $0.5 \mathrm{~m}, 49$ bins \\
\hline ADCP $1200 \mathrm{~Hz}$ (Gimbal) & 2.3 & Bin size $0.5 \mathrm{~m}, 49$ bins \\
\hline
\end{tabular}

flows. Figure 3 shows an example of the despiking algorithm on the data. It can be seen that the method properly removes the spikes. It has to be noted that the data were very clean and only a few spikes were found in the raw time series.

LISST data are treated directly with the manufacturer software using the calibration information of each instrument. ABS raw data have to be converted to obtain sediment concentration profile by an inversion algorithm (Betteridge et al., 2008). If the phase of the backscattered signal from a suspension of sediments is randomly distributed between $0-2 \pi$, the backscattered signal from a multi-frequency ABS can be converted to concentration and mean particle size (Sheng and Hay, 1988; Hay, 1991; Thorne and Campbell, 1992; Thorne and Hanes, 2002). Although using multi-frequency can be used to obtain profiles of particle size and concentration, at this stage in the analysis, advantage has been taken of the sediment trap data located on the frames to obtain estimates for the suspended particle size, and the ABS inversion used these sizes to calculate suspended sediment concentration profiles (Bolaños et al., 2009).

Wave parameters can be obtained from ADCP or from combining ADV and pressure data. The PUV method (Gor-
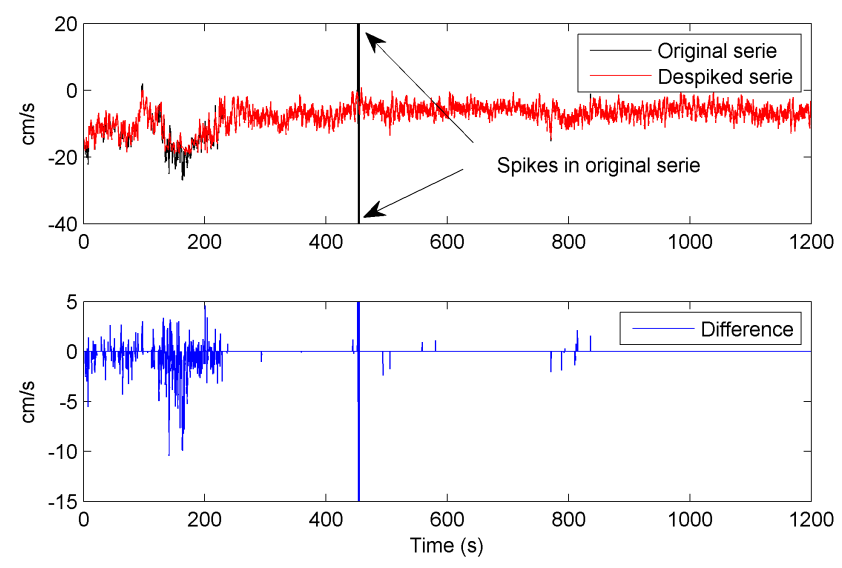

Figure 3. Top: Example of original and despiked ADV time series. Bottom: difference between the series shown in the top panel. Horizontal axis shows time, sampling frequency was of $8 \mathrm{~Hz}$.

don and Lohrmann, 2001; Longuet-Higgins, et al., 1963) has been used to obtain wave parameters from ADV and pressure. The method uses linear theory to convert velocity and 
pressure spectra to surface elevation spectra:

$$
\begin{aligned}
C_{\eta \mathrm{p}} & =\left[\frac{\cosh (k h)}{\cosh (k(h+z)}\right]^{2} \frac{C_{\mathrm{p}}}{\rho^{2} g^{2}} \\
C_{\eta \mathrm{u}} & =\left[\frac{\sinh (k h)}{\cosh (k(h+z)}\right]^{2} \frac{C_{\mathrm{u}}}{\sigma^{2}}
\end{aligned}
$$

where $C_{\eta \mathrm{p}} C_{\eta \mathrm{u}}$ are surface elevation spectra based on pressure $\left(C_{\mathrm{p}}\right)$ and velocity $\left(C_{\mathrm{u}}\right)$ spectra, $k$ is wave number, $h$ is the mean water depth relative to the seabed, $z$ is the vertical distance relative to the mean water level, $g$ is gravity and $\rho$ is water density. The frequency limits were set to 0.03 for the lowest frequency and when $\cosh (k h)=200$ for the high frequency.

In order to take into account the background currents the surface wave dispersion relation has been modified following Wolf (1997):

$\omega=\sqrt{g k \tanh k H}+k U \cos \alpha$

$\omega$ is frequency

$k$ is the wave number

$U$ is the background velocity

$\alpha$ angle between currents and waves

The wave direction is estimated by comparing the magnitude of the cross spectra at each frequency $(f)$ :

$D=\tan ^{-1}\left(C_{p u}(f) / C_{p v}(f)\right)$

$C_{\mathrm{p} u}$ Cross spectra of pressure and $u$ component

$C_{\mathrm{p} v}$ Cross spectra of pressure and $v$ component

The PUV method is very convenient because it only requires a single point velocity and pressure estimations.

The data are being banked at BODC (British Oceanographic Data Centre, http://www.bodc.ac.uk) which is the formal British organization for looking after and distributing data concerning the marine environment. The data can be provided from the authors or from S. Gaffney (sgaf@bodc. ac.uk, at BODC). The data policy is consistent with legal frameworks, such as the Environmental Information Regulations 2004 and the INSPIRE Regulations 2009. The policy involves a period of 2 years after the collection of the data before it can become available to the public.

\section{Environmental conditions during the 2008 deploy- ment period}

\subsection{Hydrodynamics}

Time series of hydrodynamic parameters at Hilbre channel and Welsh channel during the deployment period are shown in Fig. 4. Current speed is controlled by tides and it follows the spring/neap and flood/ebb cycle. Velocities at Hilbre channel are slightly larger during flood. The Hilbre channel presents larger velocities than the Welsh channel probably
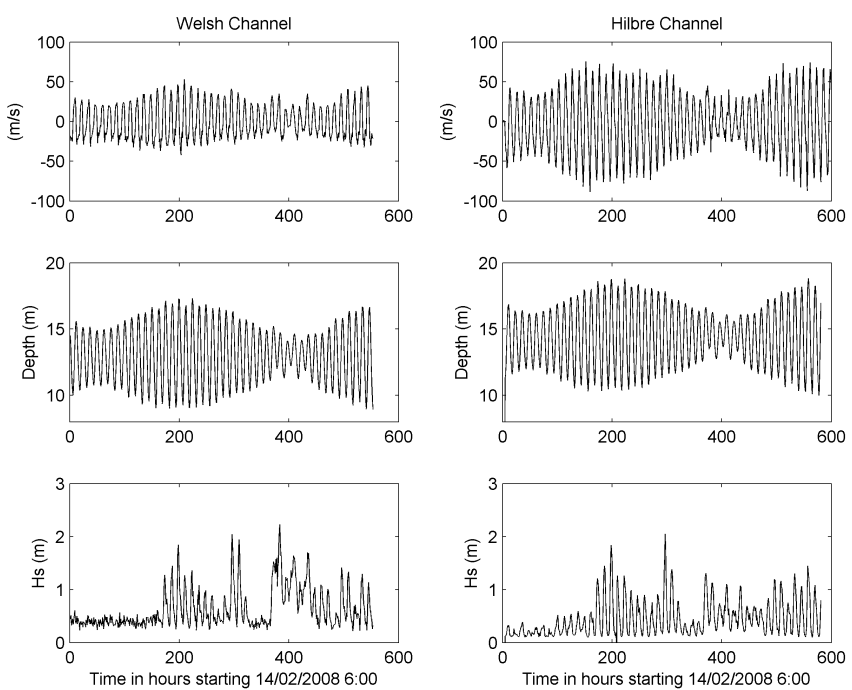

Figure 4. Time series of hydrodynamics at the Welsh Channel (left) and at Hilbre Channel (right). Top panel is current velocity (positive is flood and negative is ebb). Middle panel is water depth. Bottom panel is significant wave height.

due to its position in reference to the central part of the channel. Wave parameters are modulated by tide. The wave event during the second neap period, observed in the Welsh channel, is not present in the Hilbre channel due to a possible dissipation of energy when waves propagate in the estuary mouth. Current direction (not shown) at the Hilbre channel location is aligned with $\mathrm{N}-\mathrm{S}$ while at the Welsh channel is E-W. The ebbs at the Welsh channel produce a change in current direction that could be attributed to eddy formation due to curvature of channel, interaction with the fame and with the coastline ledge. Wave direction is predominantly from $\mathrm{E}$ and NE at the Welsh channel, however at the Hilbre predominant directions are from north, in agreement with the channel orientation. Mean periods in the area range from 3-6s and peak period from $4-10 \mathrm{~s}$.

\subsection{Sediment in suspension}

The LISST is used to provide an estimate of sediment size distribution in the area. Sediment size distributions during the first days of deployment at STABLE-III and miniSTABLE are shown in Fig. 5, because cohesive sediment particles tend to form complex structures, called aggregates or flocs, due to cohesive or adhesive forces which could sometimes also incorporate sand particles and contain a large amount of water which are much larger than the individual floc-building particles, the distributions have been selected to correspond to times when the smallest particles dominate (to reduce possible shifting of the size distribution due to flocculation) in order to provide an insight of the floc-building particle size distribution. It shows a dominance of small particles with a diameter of around 70 microns which represent 


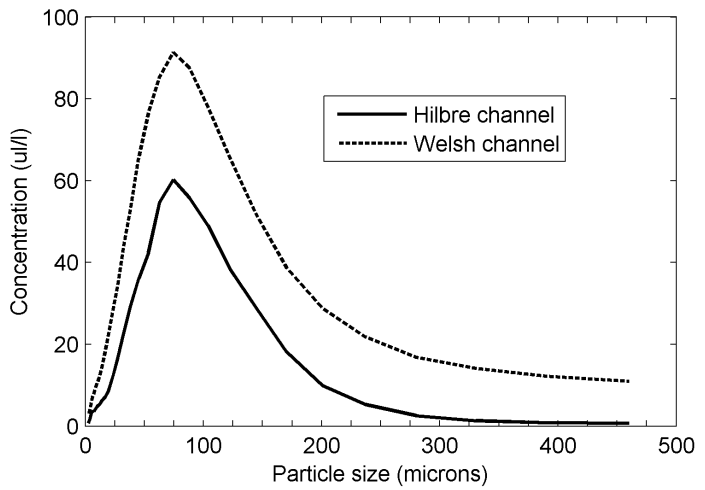

Figure 5. Size distribution of suspended sediment during the first day of deployment.
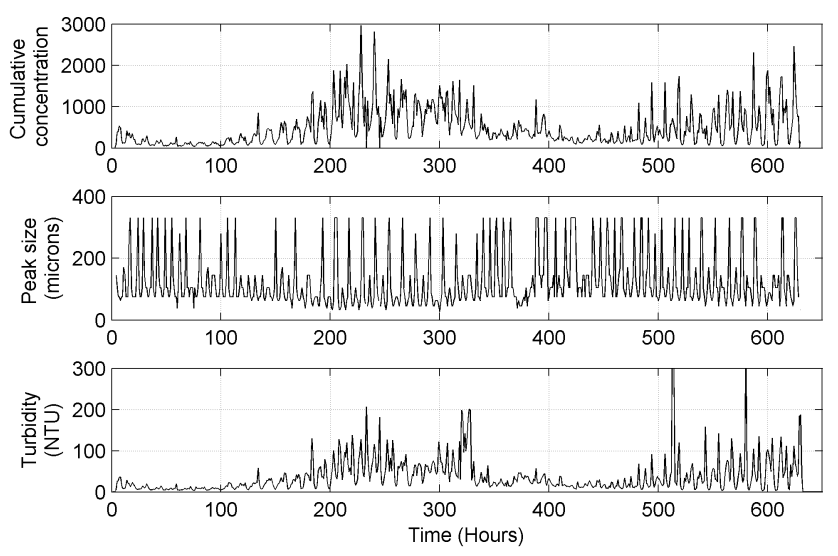

Figure 6. Time series of integrated parameters from the LISST. Top panel is the concentration. Second panel is the peak size. Third panel is the turbidity from the OBS sensor.

the limit between silt and very fine sand, there is also an important contribution of fine sand (130-250 microns). Both locations show the same pattern in size distribution, but larger concentrations at the Welsh channel possibly due to its more exposed location to wave activity and its closer position to the bed. The large concentration of cohesive particles could support the formation of flocs at some stage of the tidal cycle.

Figure 6 shows time series of integrated parameters from the LISST and the OBS at STABLE-III. The suspended sediment concentration from the LISST is not clearly related to flood and ebb but there is a signal that correlates with the spring-neap cycle. The peak size of the distribution shows that, in contrary to concentration, large particles are present for both spring and neap tides and this might be controlled by flood and ebb cycle. The turbidity data from the OBS show a very similar pattern to the concentration from the LISST showing a large correlation and a strong neap/spring signal. The mild wave events have a slight effect on sediment concentration from the LISST. A rise of concentration and turbidity in the burst 380 that agrees with a wave
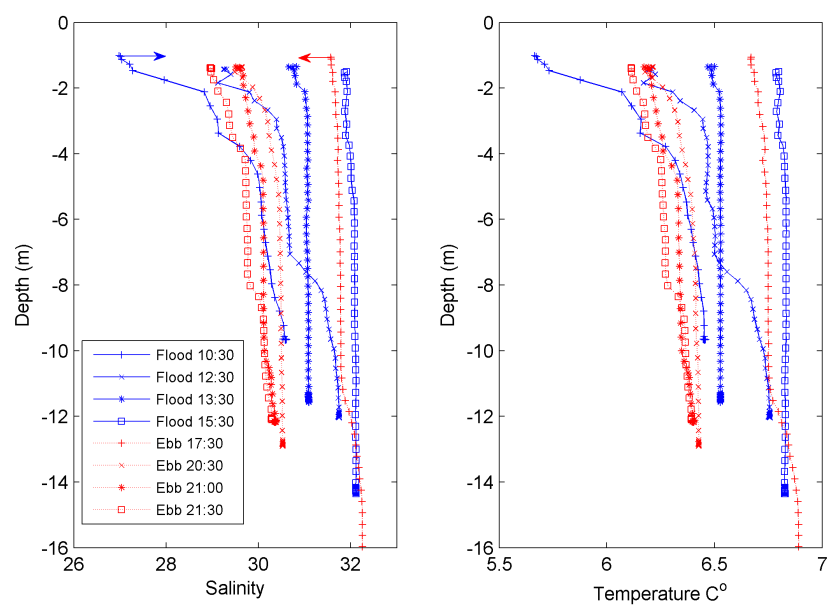

Figure 7. Samples of salinity and temperature profiles in the Hilbre Channel during the 14 February 2008. The arrows show the direction at which the profile moves at the start of flood (blue) and ebb (red).

event can be observed. The concentration presents large scatter when compared with velocities from ADVs. This shows that the concentration at about $1.5 \mathrm{~m}$ above the bed is not a pure representation of bottom processes but it could also involve some flocculation and small particle processes that might need longer time to react to environmental conditions.

\subsection{CTD stations}

Even though the Dee Estuary is tidal dominated, the stratification can be important in turbulence and transport processes. CTD stations were performed taking advantage of the deployment and recovery manoeuvres of the rigs. Stations were performed every half hour during $24 \mathrm{~h}$ if the weather and timing for entering/exiting the channels allowed it. An example of the salinity and temperature profiles in the Hilbre Channel are presented in Fig. 7 where the tidal oscillation of surface stratification can be observed. Close to low tide, a surface low density layer is present, meanwhile near high tide the profiles become more monotonic and with larger salinity due to the entrance of the saline water. The flood currents rise salinity and mix the water column while ebb currents decrease salinity mainly at the surface and produce stratification.

\section{Complementary data}

Other field measurements have been performed in the Dee Estuary by POL, rig deployment and cruises have been taking place since 2004 to collect hydrodynamic, sediment in suspension and bedform data, measuring turbulence and intra-wave processes. Tables 3 to 7 summarize the data available that have been collected. 2004 was the year the Dee Estuary experiment started involving the deployment of 
Table 3. Summary of the March 2004 data.

\begin{tabular}{llll}
\hline Location & Rig/position & Instrumentation & Other data \\
\hline Hilbre Channel & STABLE-II & Ripple profiler & CTD \\
& $53^{\circ} 23.422^{\prime} \mathrm{N}$ & LISST & Grab sample \\
& $03^{\circ} 14.217^{\prime} \mathrm{W}$ & ABS & \\
\cline { 2 - 4 } & Bed-frame & ADCP & \\
& $53^{\circ} 22.773^{\prime} \mathrm{N}$ & Current meter & \\
& $03^{\circ} 14.113^{\prime} \mathrm{W}$ & & \\
\hline Welsh Channel & Bed-frame & ADCP & CTD \\
& $53^{\circ} 22.156^{\prime} \mathrm{N}$ & 2 ADV & \\
& $03^{\circ} 19.351^{\prime} \mathrm{W}$ & LISST & \\
\hline
\end{tabular}

Table 4. Summary of the February 2005 data.

\begin{tabular}{llll}
\hline Location & Rig/position & Instrumentation & Other data \\
\hline Hilbre Channel & STABLE-II & 2 ADVs & CTD \\
& $53^{\circ} 22.340^{\prime} \mathrm{N}$ & Ripple profiler & Grab sample \\
& $03^{\circ} 14.062^{\prime} \mathrm{W}$ & LISST & Side-scan \\
& & $\mathrm{CT}$ & sonar \\
& & ABS & \\
\cline { 2 - 4 } & Bed-frame & ADCP & \\
& $53^{\circ} 22.629^{\prime} \mathrm{N}$ & & \\
& $03^{\circ} 4.213^{\prime} \mathrm{W}$ & & Side-scan \\
& Bed-frame & LISST & \\
\hline Welsh Channel & B3 $^{\circ} 22.202^{\prime} \mathrm{N}$ & ADCP & sonar \\
& $03^{\circ} 19.517^{\prime} \mathrm{W}$ & & \\
\hline
\end{tabular}

STABLE and two bed frames. Similar deployments took place during 2005 and 2006. In 2007, the deployments were extended including Mini-STABLE and the addition of more instruments into the rigs.

Similar to the 2008 campaign, the 2009 was funded by the FORMOST NERC project and it involved the deployment of Mini-Stable and STABLE-III but also included the idea of looking at biological effects, hence it included chlorophyll sampling and two deployments (winter and spring).

\section{Conclusions}

This work has presented a data set that comprises measurements of the relevant bottom processes focused to significantly advance the understanding of critical aspects of the key sediment transport processes, for example, bedform evolution, modes of sediment entrainment and the impact of mixed sediments in combined waves and currents and contribute to the improvement of its modelling. The Dee Estuary presents particular features, making it an interesting site to study not only because of its local importance but because of the mixed processes taking place there involving tidal hydrodynamics, wave events, sand and cohesive sediment, biological activity and river influence.
Table 5. Summary of the February 2006 data.

\begin{tabular}{llll}
\hline Location & Rig/position & Instrumentation & Other data \\
\hline Hilbre Channel & STABLE-II & 2 ADVs & Side-scan \\
& $53^{\circ} 22.231^{\prime} \mathrm{N}$ & Ripple profiler & sonar \\
& $03^{\circ} 14.016^{\prime} \mathrm{W}$ & LISST & CTD \\
& & ABS & SMP from \\
& & CT & water samples \\
\cline { 2 - 4 } & Bed-frame & ADCP & \\
& $53^{\circ} 22.944^{\prime} \mathrm{N}$ & & \\
& $03^{\circ} 14.216^{\prime} \mathrm{W}$ & & \\
\hline Welsh Channel & Bed-frame & ADCP & \\
& $53^{\circ} 22.196^{\prime} \mathrm{N}$ & & \\
& $03^{\circ} 19.471^{\prime} \mathrm{W}$ & & \\
\hline
\end{tabular}

Table 6. Summary of the March 2007 data.

\begin{tabular}{llll}
\hline Location & Rig/position & Instrumentation & Other data \\
\hline Hilbre Channel & STABLE-III & ADCP & CTD \\
& $53^{\circ} 23.151^{\prime} \mathrm{N}$ & LISST & Grab samples \\
& $03^{\circ} 14.391^{\prime} \mathrm{W}$ & Ripple profiler & SMP from \\
& & ABS & water samples \\
& & 3 ADV & Side-scan \\
& & Pressure sensor & sonar \\
& & 2 OBS & \\
\hline \multirow{2}{*}{ Welsh Channel } & Mini- & ADCP & CTD \\
& STABLE $^{\circ}$ & 3 ADVs & Grab samples \\
& $53^{\circ} 22.047^{\prime} \mathrm{N}$ & Ripple scanner & SMP from \\
& $03^{\circ} 19.401^{\prime} \mathrm{W}$ & ABS & water samples \\
& & Sediment trap & Side-scan \\
& & LISST & sonar \\
\hline
\end{tabular}

Sediment transport data are usually sparse and the data available are normally under relatively narrow sediment size conditions. Data in mixed sediment conditions are less frequent and thus the sediment transport processes occurring in such environments are less understood, which means this data set is a very valuable source of information as it covers several years and winter-summer periods under mild and moderate wave events. Simultaneous measurements of hydrodynamics, bed features, turbulence and suspended sediment concentration were performed considering high frequency sampling in order to obtain information on fast processes such as intrawave sediment entrainment and breaking and formation of flocs. In the representation of quite complex coastal areas, sand transport and morphological models still tend to rely on rather rudimentary transport concepts that often do not include, even in a simplified parameterised form, such fundamental mechanisms as the "wave-related" component of the transport that arises from intra-wave processes. 
Table 7. Summary of the 2009 data.

\begin{tabular}{|c|c|c|c|c|}
\hline Year and month & Location & Rig/position & Instrumentation & Other data \\
\hline \multirow[t]{2}{*}{2009 February } & Hilbre Channel & $\begin{array}{l}\text { STABLE-III } \\
53^{\circ} 22.529^{\prime} \mathrm{N} \\
03^{\circ} 14.205^{\prime} \mathrm{W}\end{array}$ & $\begin{array}{l}3 \text { ADVs } \\
\text { ABS } \\
\text { Ripple profiler } \\
3 \text { OBS } \\
\text { Sediment trap } \\
\text { ADCP } \\
\text { MicroCAT } \\
\text { LISST }\end{array}$ & $\begin{array}{l}\text { Side-scan sonar } \\
\text { CTD } \\
\text { SPM-chlorophyll } \\
\text { sampling } \\
\text { Grabs }\end{array}$ \\
\hline & Welsh Channel & $\begin{array}{l}\text { Mini-STABLE } \\
53^{\circ} 22.248^{\prime} \mathrm{N} \\
03^{\circ} 19.571^{\prime} \mathrm{W}\end{array}$ & $\begin{array}{l}2 \text { ADVs } \\
\text { ABS } \\
\text { Ripple scanner } \\
\text { Sediment trap } \\
\text { ADCP } \\
\text { MicroCAT } \\
\text { LISST }\end{array}$ & $\begin{array}{l}\text { Side-scan sonar } \\
\text { CTD } \\
\text { SPM-chlorophyll } \\
\text { sampling } \\
\text { Grabs }\end{array}$ \\
\hline \multirow[t]{2}{*}{2009 May } & Hilbre Channel & $\begin{array}{l}\text { STABLE-III } \\
53^{\circ} 22.514^{\prime} \mathrm{N} \\
03^{\circ} 14.156^{\prime} \mathrm{W}\end{array}$ & $\begin{array}{l}3 \text { ADVs } \\
\text { ABS } \\
\text { Ripple profiler } \\
3 \text { OBS } \\
\text { Sediment trap } \\
\text { ADCP } \\
\text { MicroCAT } \\
\text { LISST }\end{array}$ & $\begin{array}{l}\text { Side-scan sonar } \\
\text { CTD } \\
\text { SPM-chlorophyll } \\
\text { sampling } \\
\text { Grabs }\end{array}$ \\
\hline & Welsh Channel & $\begin{array}{l}\text { Mini-STABLE } \\
53^{\circ} 22.138^{\prime} \mathrm{N} \\
03^{\circ} 19.782^{\prime} \mathrm{W}\end{array}$ & $\begin{array}{l}2 \text { ADVs } \\
\text { ABS } \\
\text { Ripple scanner } \\
\text { Sediment trap } \\
\text { ADCP } \\
\text { MicroCAT } \\
\text { LISST }\end{array}$ & $\begin{array}{l}\text { Side-scan sonar } \\
\text { CTD } \\
\text { SPM-chlorophyll } \\
\text { sampling } \\
\text { Grabs }\end{array}$ \\
\hline
\end{tabular}

This data set is ideal for testing hydrodynamic, turbulence and sediment transport models and critically assess the improvement in the transport predictions that arise from the inclusion of a range of detailed transport processes. These include improved bed roughness prediction, representation of the "wave-related" transport component, effects of a mixed sediment bed and the extent to which our predictive capabilities related to sand transport remain valid in a mixed sediment environment.

Acknowledgements. The authors would like to thank the Prince Madog crew for their support during the deployment and recovery of the moorings. Support from the engineering group at POL is greatly acknowledged. This work was partially funded by NERC FORMOST project and NERC Oceans 2025 programme. Authors thank the support from S. Gaffney at BODC.

\section{References}

Baumert, H., Chapalain, G., Smaoui, H., McManus, J. P., Yagi, H., Regener, M., Sundermann, J., and Szilagy, B.: Modelling and numerical simulation of turbulence, waves and suspended sediments for pre-operational use in coastal seas, Coast. Eng., 41, 63-93, 2000.

Betteridge, K. F. E., Thorne, P. D., and Cook, R. D.: Calibrating multi-frequency acoustic backscatter system for studying nearbed suspended sediment transport processes, Cont. Shelf Res., 28, 227-235, 2008.

Bolaños, R., Riethmuller, R., Gayer, R., and Amos, C. L.: Sediment transport in a tidal lagoon subject to varying winds evaluated with a coupled current-wave model, J. Coast. Res., 21, e11e26, 2005.

Bolaños, R., Moate, B., and Souza, A.: Measuring suspended sediment and its wave and turbulent forcing in the Dee estuary, Proceedings of the Coastal Dynamics, ISBN-13: 978-981-4282-468, paper 119, 2009. 
Brown, J. M. and Wolf, J.: Coupled wave and surge modelling for the eastern Irish Sea and implications for model wind-stress, Cont. Shelf Res., 29, 1329-1342, 2009.

Crawford, A. M. and Hay, A. E.: Determining suspended sand size and concentration from multifrequency acoustic backscatter, J. Acoust. Soc. Am., 94, 3312-3343, 1993.

GOOS: The integrated strategic design plan for the coastal ocean observations module of the global ocean observing system, 190, 2003.

Gordon, L. and Lohrman, A.: Near-shore Doppler current meter wave spectra, Ocean wave measurement and analysis, ASCE Waves 2001 Conference, 33-43, 2001.

Goring, D. G. and Nikora, V. I.: Despiking acoustic Doppler velocimeter data, J. Hydrau. Eng., 128(1), 117-126, 2002.

Hay, A. E.: Sound scattering from a particle-laden turbulent jet, J. Acoust. Soc. Am., 90, 2055-2074, 1991.

Hutchinson, S. M.: Distribution of ${ }^{137} \mathrm{Cs}$ in saltmarsh sediments in the Dee Estuary, NW England, Mar. Pollut. Bull., 28, 4, 262265, 1994.

Hutchinson, S. M. and Prandle, D.: Siltation in the saltmarsh of the Dee Estuary derived from ${ }^{137} \mathrm{Cs}$ analysis of shallow cores, Estuar. Coast. Shelf S., 38, 5, 471-478, 1994.

Longuet-Higgins, M. S., Cartwright, D. E., and Smith, N. D.: Observations of the directional spectrum of the sea waves using the motions of a floating buoy, Ocean Wave Spectra, Prentice-Hall, 111-136, 1963.

Mastenbroek, C., Burgers, G., and Janssen, P. A. E. M.: The dynamical coupling of a wave model and a storm surge model through the atmospheric boundary layer, J. Phys. Oceanogr., 23, 18571866, 1993.

Moore, R. D., Wolf, J., Souza, A. J., and Flint, S. S.: Morphological evolution of the Dee Estuary, Eastern irish sea, UK: a tidal asymmetry approach, Geomorphology, 103, 588-596, 2009.

Mori, N., Suzuki, T., and Kakuno, S.: Noise of Acoustic Doppler Velocimeter data in bubbly flows, J. Eng. Mechanics, 133, 122125, 2007.

Pinardi, N. and Woods, J.: Ocean Forecasting, Conceptual basis and applications, Springer, 2002.
Sheng, J. and Hay, A. E.: An examination of the spherical scatterer approximation in aqueous suspensions of sand, J. Acoust. Soc. Am., 83, 598-610, 1988.

Simpson, J. H., Fisher, N. R., and Wiles, P.: Reynolds stress and TKE production in an estuary with a tidal bore, Estuarine, Coast. Shelf Sci., 60, 619-627, 2004.

Souza, A. J., Dickey, T. D., and Chang, G. C.: Modeling water column structure and suspended particulate matter on the Middle Atlantic continental shelf during the passages of Hurricanes Edouard and Hortense, J. Mar. Res., 59, 1021-1045, 2001.

Styles, R.: Laboratory evaluation of the LISST in a stratified fluid, Mar. Geol., 227, 151-162, 2006.

Thorne, P. D. and Campbell, S. C.: Backscattering by a suspension of spheres, J.Acost. Soc. Am., 92, 978-986, 1992.

Thorne, P. D. and Hanes, D. M.: A review of acoustic measurements of small-scale sediment processes, Cont. Shelf Res., 22, 603632, 2002.

Wahl, T. L.: Discussion of "Despiking acoustic doppler velocimeter data”, J. Hydr. Eng., 129(6), 484-487, 2003.

Williams, J. J., Bell, P. S., Coates, L. E., Metje, N., and Selwyn, R.: Interactions between a benthic tripod and waves on a sandy bed, Cont. Shelf Res., 23, 355-375, 2003.

Williams, J. J., Bell, P. S., Thorne, P. D., Metje, N., and Coates, L. E.: Measurement and prediction of wavegenerated suborbital ripples, J. Geophys. Res., 109, C02004, doi:10.1029/2003JC001882, 2004.

Williams, J. J., Bell, P. S., and Thorne, P. D.: Unifying large and small wave-generated ripples, J. Geophys. Res., 110, C02008, doi:10.1029/2004JC002513, 2005.

Wolf, J.: The analysis of bottom pressure and current data for waves, Proceedings of the 7th International Conference on Electronic Engineering in Oceanography, Southampton, Conference Publication 439, 1997.

Young, R. A., Merrill, J. T., Clarke, T. L., and Proni, J. R.: Acoustic profiling of suspended sediments in the marine bottom boundary layer, Geophys. Res. Lett., 9, 175-178, 1982. 